\title{
Evaluating the effects of different protocols applied to resected root end on apical
}

\author{
Gülter Devrim Kaki, ${ }^{1}$ Mukadder İnci Başer Kolcu, ${ }^{2}$ Serap Keskin Tunç ${ }^{3}$ \\ 'Department of Endodontics, Uşak University Faculty of Dentistry, Uşak, Turkey \\ ${ }^{2}$ Turkish Governments, Ministry of Health, Isparta Oral and Health Centre, Isparta, Turkey \\ ${ }^{3}$ Department of Oral and Maxillofacial Surgery, Van Yüzüncü Yıl University Faculty of Dentistry, Van, Turkey
}

Objective: This study aimed to investigate the effects of different protocols applied to the resected root end on apical sealing.

Methods: In this study, 35 permanent lower premolars were chemomechanically prepared and obturated. Three $\mathrm{mm}$ of the root end was resected, and a 3-mm retro cavity was prepared using an erbium, chromium: yttrium-scandium-gallium-garnet ( $\mathrm{Er}, \mathrm{Cr}$ : YSGG) laser. The roots were randomly divided into four groups according to the protocol applied: group 1 (control group): no treatment was performed $(n=5)$, group 2: Biodentine sealing $(n=10)$, group 3: Biodentine sealing $+E r, C r$ : YSGG application, and group 4: only Er, Cr: YSGG application. The fluid filtration model was tested. The results were evaluated using one-way analysis of variance.

Results: All groups showed leakage. No statistically significant difference was found between the groups $(p \leq 0.05)$. The largest leak average was observed in group $1(0.000373640 \pm 0.000135817 \mathrm{Lp})$ and the smallest leak $(0.000270134 \pm 0.000136416 \mathrm{Lp})$ in group 3 .

Conclusion: The protocols applied did not completely prevent leakage of the resected root end; however, the use of Biodentine and the Er, Cr: YSGG laser led to less leakage.

Keywords: Apical leakage; Biodentine; chromium; endodontics; erbium; yttrium-scandium-galliumgarnet laser.

Surgical endodontic treatment (SET) is considered $\checkmark$ when nonsurgical treatment (NSET) is impossible or unanswered. Root-end resection, apical cavity preparation, and apical seal are recommended for successful SET. ${ }^{[1]}$ Root-end resection with no bevel is recommended because a bevel causes more opened dentinal tubules and apical permeability. ${ }^{[1,2]}$ Apical cavity preparation is considered as a class I cavity with $3 \mathrm{~mm}$ depth and parallel walls. ${ }^{[3]}$ To make an apical cavity, a microhandpiece with rotat- ing burs, ultrasonic device with special tips, and different lasers can be used. Ultrasonic tips allow to open smaller and deeper cavities, cuts with no bevel, and facilitates better preparation of root canals with abnormal anatomic structure; ${ }^{[4]}$ however, on the other hand, they cause more microcracks, leading to failure of SET ${ }^{[5]} \mathrm{Er}$, Cr: YSGG lasers have been used in the preparation of apical cavity because of the following advantages: less microcracks, ${ }^{[6]}$ less dentin permeability, ${ }^{[7]}$ no vibration, ${ }^{[8]}$ and disinfection. ${ }^{[9]}$

Correspondence: Dr. Gülter Devrim Kaki. Uşak Üniversitesi Diş Hekimliği Fakültesi,

Endodonti Anabilim Dalı, Uşak, Turkey.

Tel: +90 533 - 3989221 e-mail: devrim.kaki@usak.edu.tr

Submitted: August 19, 2017 Accepted: October 13, 2017 
Smear layer removal and melting and solidification of root canal dentin walls are important to develop apical sealing. To remove smear layer, different types of laser are recommended. ${ }^{[7,10,11]}$

After the preparation of root-end cavity, obturation of the cavity with a biocompatible, impermeable material is recommended. Biodentine is one of these materials with an appropriate setting time and good handling. ${ }^{[12]}$ Biodentine is a calcium silicate-based MTA-like material that has a short setting time. Biodentine powder consists of tricalcium silicate, calcium carbonate (filler), and zirconium dioxide (radiopacifier). Biodentine liquid contains calcium chloride (setting accelerator), super plasticizer, and water. ${ }^{[13]}$ According to the manufacturer, Biodentine can be used for pulp capping, pulpotomy, apexification, root perforation, internal and external resorption, and also as a root-end filling material in periapical surgery. Biodentine is found to be biocompatible and inductive for odontoblasts. ${ }^{[14]}$

Er, Cr: YSGG laser has some advantages such as different settings can cause different results on root canal dentin, ${ }^{[15,16]}$ According to Gholami et al. (2011), Er, Cr: YSGG laser is the second choice of treatment for dentin hypersensitivity because of its ability to occlude dentinal tubules. ${ }^{[17]}$ In this study, similar to dentine hypersensitivity treatment levels, our pilot study levels (unpublished data) had been used to occlude dentinal tubules. The aim of this study was to investigate the effects of low level Er, Cr: YSGG laser application on the apical area of the root on the leakage with the fluid filtration model.

\section{Materials and methods}

Thirty-five human single-rooted lower premolar teeth stored until use in thymol solution to prevent bacterial growth were used. Each single-rooted tooth was cleaned and crowns were separated from the cementoenamel junction. Instrumentation of the roots was performed with a crown-down technique using WaveOne nickel-titanium rotary instruments (Dentsply-Maillefer, U.S.A ). The canals were rinsed with $10 \mathrm{~mL} \mathrm{5 \%}$ sodium hypochlorite in between instrumentation and $5 \mathrm{~mL}$ of $17 \%$ ethylenediaminetetraacetic acid (EDTA) as the final rinse. The roots were filled using the cold lateral condensation method. The apical $3 \mathrm{~mm}$ of each instrumented root was resected $90^{\circ}$ to the longitudinal axis of the root. The roots were randomly divided into four groups according to the protocols applied.

Group 1 (control group): No treatment was performed $(n=5)$.

Group 2: Er, Cr: YSGG, 3-mm retro cavity was pre-

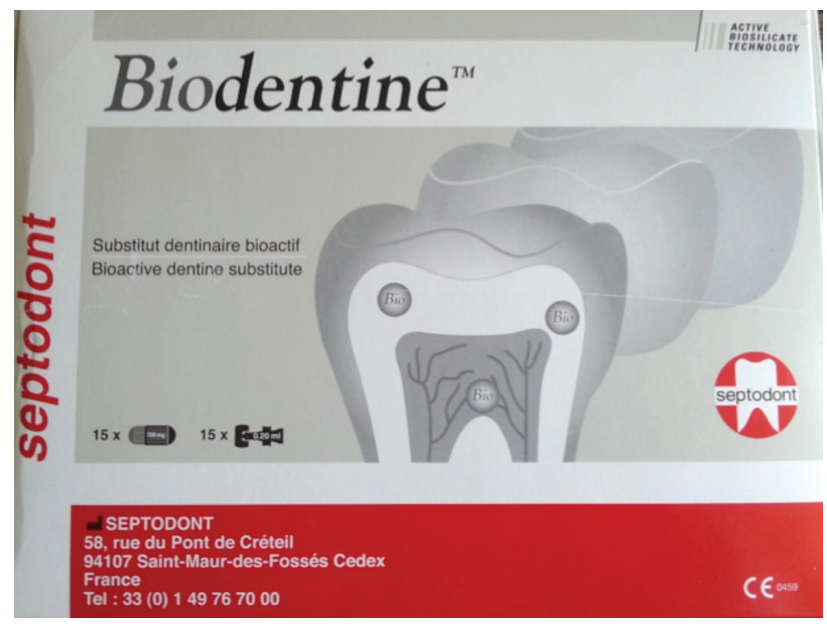

Fig. 1. Biodentine.

pared using Er, Cr: YSGG (i Plus, Biolase, U.S.A) laser (Fig. 1) (MZ5 tip, $3.5 \mathrm{~W}, 100 \%$ water, 100\% air, $20 \mathrm{~Hz}$, $\mathrm{H}$ mode), and the cavity was filled with Biodentine (Septodont, France) ( $\mathrm{n}=10)$ (Fig. 2).

Group 3: Er, Cr: YSGG, 3-mm retro cavity was prepared using Er, Cr: YSGG (MZ5 tip, $3.5 \mathrm{~W}, 100 \%$ water, $100 \%$ air, $20 \mathrm{~Hz}, \mathrm{H}$ mode), and the cavity was filled with Biodentine. The dentinal tubules were melted using Er, Cr: YSGG laser (MZ6 tip, $0.50 \mathrm{~W}, 0 \%$ water, $0 \%$ air, 20 $\mathrm{Hz}, \mathrm{H}$ mode) $(\mathrm{n}=10)$.

Group 4: Only the dentinal tubules were melted using Er, Cr: YSGG laser (MZ6 tip, $0.50 \mathrm{~W}, 0 \%$ water, $0 \%$ air, $20 \mathrm{~Hz}, \mathrm{H}$ mode $)(\mathrm{n}=10)$.

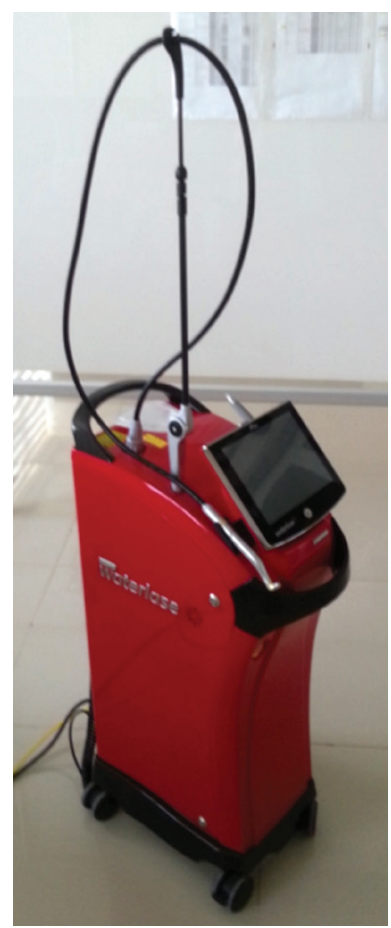

Fig. 2. $E r$, Cr: YSGG laser (MZ5 tip, $3.5 \mathrm{~W}, 100 \%$ water, $100 \%$ air, $20 \mathrm{~Hz}, \mathrm{H}$ mode) was used to open retro cavity and to occlude dentinal tubules (MZ6 tip, $0.50 \mathrm{~W}, 0 \%$ water, $0 \%$ air, $20 \mathrm{~Hz}, \mathrm{H}$ mode). 


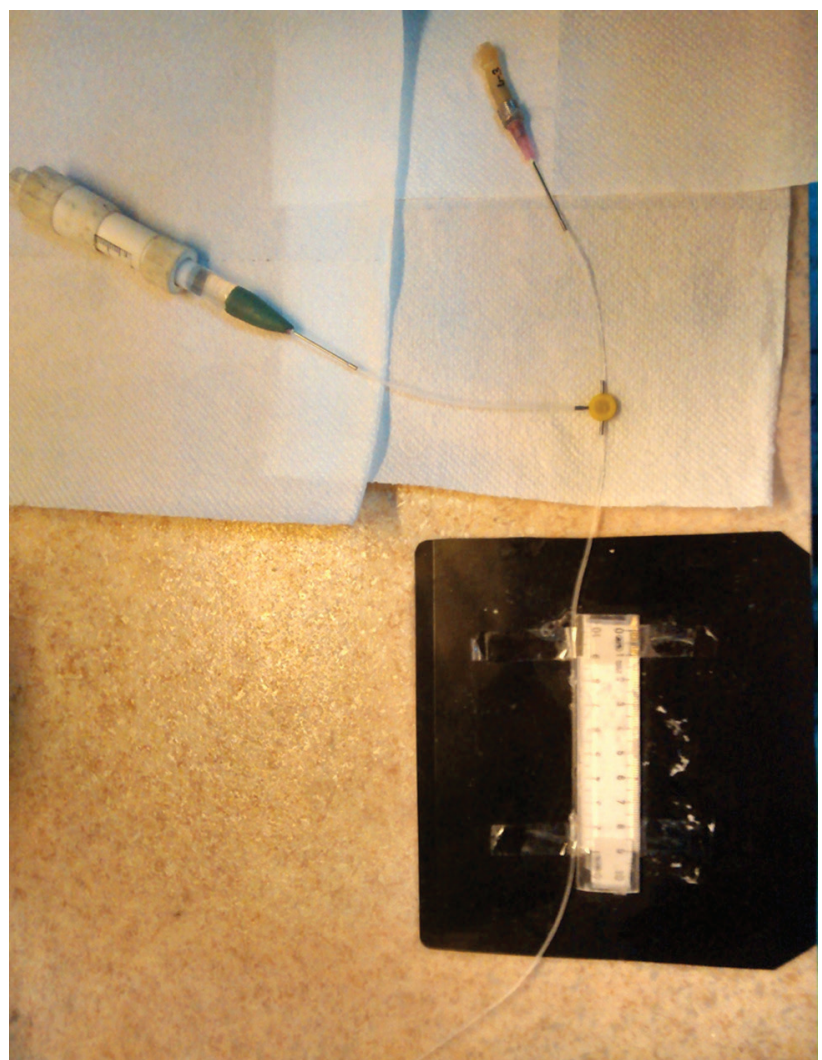

Fig. 3. Fluid filtration test.

To investigate apical leakage, the test method of fluid filtration, as reported by Pashley and Depew, was used. ${ }^{[18]}$ The plastic tube was attached to the prepared specimens with fast-setting cyanoacrylate adhesive (Pattex, Henkel). Then, this plastic tube was connected to the fluid filtration apparatus. Another tube was connected to the micropipette. In this tube, an air bubble was created with a micro-syringe. All tubes, pipettes, and syringes were filled with distilled water under a pressure of 1 atmosphere with $\mathrm{O} 2$ gas. Apical sealing was measured by the mobilization of this air bubble in the glass capillary system under constant pressure. The movement of the air bubble was recorded every $3 \mathrm{~min}$. The mean value of four measurements was averaged, and the amount of the fluid passing through the root was calculated in $\mathrm{L} / \mathrm{min}$ (Fig. $3)$. The results were evaluated using one-way ANOVA.

\section{Results}

Apical leakage was observed in all groups. No statistically significant difference was found among the groups. The highest apical leakage was found in group 1 and the lowest one in group 3. The results of the quantitative evaluation of the apical leakage properties of the four groups are shown in Table 1.

\section{Discussion}

Studies have shown that even after root canal treatment, microorganisms can still survive in root canals. ${ }^{[19]}$ It is also known that these microorganisms require nutrients to survive. Because of the importance of sealing of the root canals, studies on apical and coronal sealing have been an ongoing research topic in endodontics. The purpose of this study was to investigate the effects of different protocols on apical sealing. This study investigated whether there was any advantage of melting the root-end dentinal tubules with the Er, Cr: YSGG laser after using Biodentine as a root-end filling material or whether only melting the root-end with Er, Cr: YSGG laser was sufficient.

When nonsurgical root canal treatment fails or is impossible, surgical root canal treatment can be performed. In endodontic surgery, the amount of resection of the root-end and the angle of resection are two of the important steps. Although the anatomy of the roots is complex, approximately $75 \%$ of accessory and lateral canals are located in the apical $3 \mathrm{~mm}$ of the root. ${ }^{[3]}$ Because of this, resection of the apical $3 \mathrm{~mm}$ of the root end is recommended to reduce residual etiologic factors (such as irritants, microorganisms, and anatomical formations that can lead to leaks). For simpler preparation of the root-end cavity, elimination of the anatomic ramifications is recommended; for decreasing the number of dentinal tubules present between the surgical site and the root canals, perpendicular root resection is recommended. ${ }^{[20-22]}$ Beveled root-end resection increases the risk of apical microleakage. ${ }^{[20]}$ So, in the present study, perpendicular root-end resection of the apical $3 \mathrm{~mm}$ of the roots was performed for simulation of ideal clinical condition.

The ideal root-end cavity is described as a class I cav-

Table 1. Quantitative evaluation of apical leakage properties of four groups

\begin{tabular}{lccc}
\hline & $\mathbf{n}$ & Average Leakage Properties \\
Group 1 (control group) & 5 & $3.7336 \times 10^{-4}$ & $1.358 \times 10^{-4}$ \\
Group 2 (Er, Cr; YSGG+Biodentine) & 10 & $3.717 \times 10^{-4}$ & $3.746 \times 10^{-4}$ \\
Group 3 (Er, Cr; YSGG+Biodentine + Er, Cr; YSGG) & 10 & $2.701 \times 10^{-4}$ & $1.364 \times 10^{-4}$ \\
Group 4 (Er, Cr; YSGG) & 10 & $3.034 \times 10^{-4}$ & $1.614 \times 10^{-4}$ \\
\hline
\end{tabular}

Values are means $\pm S D$. $P=0.05$ significant level. Letter shows statistically differences. 
ity with $3 \mathrm{~mm}$ depth and parallel to the long axis of the root. ${ }^{[3]} \mathrm{A}$ microhandpiece with rotating burs, ultrasonic device with special tips, and different lasers can be used for preparing a root-end cavity. Ideal cavity preparation cannot be easily done using only a microhandpiece with rotating burs. With the advanced technology, ultrasonic tips have made it easier to work. Although nowadays usually ultrasonic tips are being used for this purpose, root fractures and microcracks caused by ultrasonic tips have been reported. ${ }^{[5]}$ After using lasers for hard tissue removal in periradicular surgery, some advantages of $\mathrm{Er}, \mathrm{Cr}$ : YSGG laser such as occurrence of less microcracks, ${ }^{[6]}$ less dentin permeability ${ }^{[7]}$ no vibration, ${ }^{[8]}$ and disinfection ${ }^{[9]}$ were reported. Studies that attempted to determine which power values of Er, Cr: YSGG laser are most appropriate for endodontic surgery recommended different values. ${ }^{[23]}$ In a current study, $3.5 \mathrm{~W}$ has been reported as the minimum effective power. ${ }^{[24]}$ So, in this study, $3.5 \mathrm{~W}$ was used.

There are various widely used root-end filling materials such as mineral trioxide aggregate (MTA), super EBA (Harry J. Bos- worth Co., Skokie, IL), IRM (LD Caulk Co., Milford, DE), Biodentine (Septodont, Saint Maur des Fossés, France), etc. ${ }^{[25]}$ In vitro studies about sealing ability and biocompatibility have reported that MTA is superior to other commonly used materials. ${ }^{[26-28]}$ MTA is a preferable material for endodontic surgery with some properties such as well-seal ability, ${ }^{[29]}$ bioactivity, ${ }^{[30]}$ and osteogenic potential $;^{[31]}$ however, it also has some disadvantages such as difficulties in manipulation and long setting time. So, for finding different materials, researches are being continued. ${ }^{[32]}$

Biodentine is a calcium silicate-based MTA-like material that has a short setting time and good handling. ${ }^{[12]}$ A current study found that Biodentine causes lesser microleakage than MTA when used as a retrograde filling material. ${ }^{[33]}$ In this study, using Biodentine as a root-end filling material decreased the apical leakage; however, no statistically significant difference was found.

There are many methodologies introduced for assessing apical leakage in endodontic treatments. Usually, in vitro studies measure microleakage by inserting a tracer into the root canals such as dyes, bacteria, or isotopes. Dye penetration method has been widely used because of its simplicity and lower cost, ${ }^{[34]}$ but the small size of the dye molecules can cause overestimation of leakage. So, the validity and reliability of this technique is questionable. ${ }^{[35]}$ The bacterial microleakage method is the most suitable method for assessing microleakage as it is the best simulation of clinical conditions. ${ }^{[36]}$

Fluid filtration is a different method described for assessing apical microleakage. In this technique, the aim is to provide a closed circuit filled with liquid. A pressure provider, $\mathrm{T}$ tube, and sample are attached to the system. By attaching the sample to a capillary tube, the system can be closed. With the help of T tube, a bubble must be created, and with pressure, liquid should be pushed into the sample. The movement of the bubble in a specific period gives the movement of the liquid so the amount of leakage $(\mu \mathrm{l} / \mathrm{min}){ }^{[37]}$ Nondestructive process, quantitative and reproductive test results make this technique preferable. ${ }^{[38,39]}$ It was reported that because of the different pressure value, experiment time, bubble size or capillary tube diameter could change the test results, this technique was not standardized. ${ }^{[40]}$ Despite the reported disadvantages, many studies have used this method. In a current study, Moradi et al. (2015) compared two techniques, bacterial microleakage and fluid filtration, and a correlation between this two techniques was shown. ${ }^{[41]}$ They also argued that some other contrast studies showed different results, but the differences could be able to occur with the differences about the test variables such as using oxygen gas or helium gas as a pressure provider. They suggested using oxygen gas for pressure because constant pressure can be provided as in contrast of using helium gas. There are no current studies about the sealing ability of apical procedures used by us. So, this precursor study was performed by us with the aim to conduct advanced studies. In this study, fluid filtration technique was preferred because of simpler use, lower cost, and reproducible and quantitative results. To obtain standardization, oxygen gas was used, length of the specimen was kept same, and one investigator was used for all the tests, and every measurement was performed four times and the mean scores were calculated and used in this study, as recommended in the literature. ${ }^{[42,43]}$

Using Er, Cr: YSGG laser did not cause a statistically significant difference in the present study in agreement with that by Onay et al. (2014) who presented that rootend filling materials' sealing ability was not influenced by Er, Cr: YSGG laser. ${ }^{[44]}$ But Paghdiwala (1991) discovered that the thermal ablation of the Er: YAG laser can lead to dissolution of mineral components and melting of amorphous particles without crystallization and a clean and smooth surface; thus, apical microleakage can be prevented. ${ }^{[45]}$ Methodological differences can cause this contrast.

\section{Conclusion}

Based on current findings of this in vitro study, neither is $\mathrm{Er}, \mathrm{Cr}$ : YSGG laser treatment is necessary nor does it influence the apical microleakage when compared with Biodentine. We found that in all apical protocols tested in this study, apical microleakage was shown, but the combined 
use of Biodentine and Er, Cr: YSGG laser resulted in successful apical sealing. Further investigations are needed to determine the efficacy of different laser types and different settings of lasers for apical sealing.

Conflict of interest: None declared.

\section{References}

1. Tidmarsh BG, Arrowsmith MG. Dentinal tubules at the root ends of apicected teeth: a scanning electron microscopic study. Int Endod J 1989;22:184-9. [CrossRef]

2. Chong BS, Ford TR, Kariyawasam SP. Tissue response to potential root-end filling materials in infected root canals. Int Endod J 1997;30:102-14. [CrossRef]

3. De Deus QD. Frequency, location, and direction of the lateral, secondary, and accessory canals. J Endod 1975;1:3616. [CrossRef]

4. de Lange J, Putters T, Baas EM, van Ingen JM. Ultrasonic root-end preparation in apical surgery: a prospective randomized study. Oral Surg Oral Med Oral Pathol Oral Radiol Endod 2007;104:841-5. [CrossRef]

5. Abedi HR, Van Mierlo BL, Wilder-Smith P, Torabinejad M. Effects of ultrasonic root-end cavity preparation on the root apex. Oral Surg Oral Med Oral Pathol Oral Radiol Endod 1995;80:207-13. [CrossRef]

6. Wallace JA. Effect of Waterlase laser retrograde root-end cavity preparation on the integrity of root apices of extracted teeth as demonstrated by light microscopy. Aust Endod J 2006;32:35ר-9.

7. Aranha AC, Domingues FB, Franco VO, Gutknecht N, Eduardo Cde P. Effects of Er:YAG and Nd:YAG lasers on dentin permeability in root surfaces: a preliminary in vitro study. Photomed Laser Surg 2005;23:504-8. [CrossRef]

8. Aoki A, Ishikawa I, Yamada T, Otsuki M, Watanabe H, Tagami J, et al. Comparison between Er:YAG laser and conventional technique for root caries treatment in vitro. J Dent Res 1998;77:1404-14. [CrossRef]

9. Gordon W, Atabakhsh VA, Meza F, Doms A, Nissan R, Rizoiu I, et al. The antimicrobial efficacy of the erbium, chromium:yttrium-scandium-gallium-garnet laser with radial emitting tips on root canal dentin walls infected with Enterococcus faecalis. J Am Dent Assoc 2007;138:9921002. [CrossRef]

10. Bader G, Lejeune S. Prospective study of two retrograde endodontic apical preparations with and without the use of CO2 laser. Endod Dent Traumatol 1998;14:75-8.

11. Karlovic Z, Pezelj-Ribaric S, Miletic I, Jukic S, Grgurevic J, Anic I. Erbium:YAG laser versus ultrasonic in preparation of root-end cavities. J Endod 2005;31:821-3. [CrossRef]

12. Santos AD, Moraes JC, Araújo EB, Yukimitu K, Valério Filho WV. Physico-chemical properties of MTA and a novel experimental cement. Int Endod J 2005;38:443-7.

13. Goldberg M, Pradelle-Plasse N, Tran XV, Colon P, Lau- rent $\mathrm{P}$, Aubut V, et al. Emerging trends in (bio) material research. Physico-chemical properties of Biodentine. In: Goldberg M, editor. Biocompatibility or cytotoxic effects of dental composites. 1st ed. Oxford: Coxmoor Publishing; 2009. p. 181-203.

14. Zanini M, Sautier JM, Berdal A, Simon S. Biodentine induces immortalized murine pulp cell differentiation into odontoblast-like cells and stimulates biomineralization. J Endod 2012;38:1220-6. [CrossRef]

15. Corona SA, de Souza AE, Chinelatti MA, Borsatto MC, Pécora JD, Palma-Dibb RG. Effect of energy and pulse repetition rate of Er: YAG laser on dentin ablation ability and morphological analysis of the laser-irradiated substrate. Photomed Laser Surg 2007;25:26-33. [CrossRef]

16. Zapletalová Z, Perina J Jr, Novotný R, Chmelícková H. Suitable conditions for sealing of open dentinal tubules using a pulsed Nd:YAG laser. Photomed Laser Surg 2007;25:495-9. [CrossRef]

17. Gholami GA, Fekrazad R, Esmaiel-Nejad A, Kalhori KA. An evaluation of the occluding effects of $\mathrm{Er} ; \mathrm{Cr}$ :YSGG, $\mathrm{Nd}: Y A G, \mathrm{CO}_{2}$ and diode lasers on dentinal tubules: a scanning electron microscope in vitro study. Photomed Laser Surg 2011;29:115-21. [CrossRef]

18. Pashley DH, Depew DD. Effects of the smear layer, Copalite, and oxalate on microleakage. Oper Dent 1986;11:95-102.

19. Johnson BR, Mohamed IF. Periradicular Surgery. In: Hargreaves K, Berman L, editors. Cohen's Pathways of the Pulp Expert Consult. 11th ed. Mosby; 2016. p. 388.

20. Gilheany PA, Figdor D, Tyas MJ. Apical dentin permeability and microleakage associated with root end resection and retrograde filling. J Endod 1994;20:22-6. [CrossRef]

21. Mauger MJ, Schindler WG, Walker WA 3rd. An evaluation of canal morphology at different levels of root resection in mandibular incisors. J Endod 1998;24:607-9.

22. Gagliani M, Taschieri S, Molinari R. Ultrasonic root-end preparation: influence of cutting angle on the apical seal. J Endod 1998;24:726-30. [CrossRef]

23. Olivi G, Olivi M, Genovese MD. Erbium lasers in pediatric dentistry. Dent Clin 2014;30-3.

24. Batista de Faria-Junior N, Tanomaru-Filho M, GuerreiroTanomaru JM, de Toledo Leonardo R, Camargo Villela Berbert FL. Evaluation of ultrasonic and ErCr:YSGG laser retrograde cavity preparation. J Endod 2009;35:741-4.

25. Fogel HM, Peikoff MD. Microleakage of root-end filling materials. J Endod 2001;27:456-8. [CrossRef]

26. Torabinejad M, Smith PW, Kettering JD, Pitt Ford TR. Comparative investigation of marginal adaptation of mineral trioxide aggregate and other commonly used root-end filling materials. J Endod 1995;21:295-9. [CrossRef]

27. Walia H, Newlin S, Austin B. Electrochemical analysis of retrofilling microleakage in extracted human teeth. J Dent Res 1995;74:101. 
28. Lee SJ, Monsef M, Torabinejad M. Sealing ability of a mineral trioxide aggregate for repair of lateral root perforations. J Endod 1993;19:541-4. [CrossRef]

29. Torabinejad M, Rastegar AF, Kettering JD, Pitt Ford TR. Bacterial leakage of mineral trioxide aggregate as a rootend filling material. J Endod 1995;21:109-12. [CrossRef]

30. Sarkar NK, Caicedo R, Ritwik P, Moiseyeva R, Kawashima I. Physicochemical basis of the biologic properties of mineral trioxide aggregate. J Endod 2005;31:97-100.

31. Torabinejad M, Pitt Ford TR, McKendry DJ, Abedi HR, Miller DA, Kariyawasam SP. Histologic assessment of mineral trioxide aggregate as a root-end filling in monkeys. J Endod 1997;23:225-8. [CrossRef]

32. Bortoluzzi EA, Broon NJ, Bramante CM, Garcia RB, de Moraes IG, Bernardineli N. Sealing ability of MTA and radiopaque Portland cement with or without calcium chloride for root-end filling. J Endod 2006;32:897-900.

33. Nanjappa AS, Ponnappa KC, Nanjamma KK, Ponappa MC, Girish S, Nitin A. Sealing ability of three root-end filling materials prepared using an erbium: Yttrium aluminium garnet laser and endosonic tip evaluated by confocal laser scanning microscopy. J Conserv Dent 2015;18:327-30.

34. Pusinanti L, Rubini R, Pellati A, Zerman N. A simplified post preparation technique after Thermafil obturation: evaluation of apical microleakage and presence of voids using methylene blue dye penetration. Ann Stomatol (Roma) 2013;4:184-90.

35. Camps J, Pashley D. Reliability of the dye penetration studies. J Endod 2003;29:592-4. [CrossRef]

36. Moradi S, Disfani R, Baziar H, Daneshvar F, Jafarzadeh H. Use of fluid filtration method to evaluate the effect of master cone size on the apical seal of severely curved root canals. J Oral Sci 2013;55:93-8. [CrossRef]
37. Moradi S, Naghavi N, Rohani E, Javidi M. Evaluation of microleakage following application of a dentin bonding agent as root canal sealer in the presence or absence of smear layer. J Oral Sci 2009;51:207-13. [CrossRef]

38. Hirschberg CS, Patel NS, Patel LM, Kadouri DE, Hartwell GR. Comparison of sealing ability of MTA and EndoSequence Bioceramic Root Repair Material: a bacterial leakage study. Quintessence Int 2013;44:e157-62.

39. Tapsir Z, Aly Ahmed HM, Luddin N, Husein A. Sealing ability of various restorative materials as coronal barriers between endodontic appointments. J Contemp Dent Pract 2013;14:47-50. [CrossRef]

40. Pommel L, Camps J. Effects of pressure and measurement time on the fluid filtration method in endodontics. J Endod 2001;27:256-8. [CrossRef]

41. Moradi S, Lomee M, Gharechahi M. Comparison of fluid filtration and bacterial leakage techniques for evaluation of microleakage in endodontics. Dent Res J (Isfahan) 2015;12:109-14.

42. Wu MK, Wesselink PR. Endodontic leakage studies reconsidered. Part I. Methodology, application and relevance. Int Endod J 1993;26:37-43. [CrossRef]

43. Cobankara FK, Adanir N, Belli S, Pashley DH. A quantitative evaluation of apical leakage of four root-canal sealers. Int Endod J 2002;35:979-84. [CrossRef]

44. Onay EO, Gogos C, Ungor M, Economides N, Lyssaris V, Ogus E, et al. Effect of Er,Cr:YSGG laser irradiation on apical sealing ability of calcium silicatecontaining endodontic materials in root-end cavities. Dent Mater J 2014;33:570-5. [CrossRef]

45. Paghdiwala AF. Er: YAG laser hard tissue effects. In: Moretti M, editor. Lasers in dentistry. Massachusetts: Penn Well Publishing Co; 1991. p. 63-75. 